\title{
Fascism, Anti-Fascism and the Idea of Nation: Italian Historiography and Public Debate since the 1980s
}

\author{
Marco Bresciani \\ Department of Political and Social Sciences, via delle Pandette 32, 50127 Florence, Italy \\ marco.bresciani@unifi.it
}

\section{The Twilight of the Anti-Fascist Republic}

It is common to consider 1989 as a kind of 'zero hour'. This applies to East Central European and to Italian history alike. A thought-provoking book, published in 1993, evoked the image of 'an avalanche that swells downhill, speeded up and enriched by the great landslide of the nearby great mountain'. In this way the historian Luciano Cafagna described the impact of the fall of the Berlin Wall on Italian democracy. ${ }^{1}$ As a matter of fact, the Italian party system, based on the leading role of the Christian Democratic Party and of the West's major Communist Party, suddenly collapsed in the three years that followed the end of the Cold War because of a growing loss of legitimacy. ${ }^{2}$ In hindsight, though, I argue that the first, mostly invisible, movements of this 'avalanche' went further back in time, to well before 1989. The early 1990s simply marked its spectacular acceleration.

This uncertain political transition provoked vibrant debates concerning the anti-fascist foundation of post-1945 constitutional democracy and Italian national identity. In this Spotlight I will propose a trajectory that aims to link these public debates and some important research about twentieth-century Italian history, with special regard to nationalism, fascism and imperialism. I will thus include not only Italian historians but all those scholars who had an influence on the Italian disputes about twentiethcentury history, regardless of their cultural education and academic affiliation inside or outside Italy. The main argument here is that scholarship had ambivalent results: on the one hand, a small part of it gradually and partially succeeded in testing new comparative and/or transnational approaches and in highlighting new themes and problems but had a quite limited impact on the national audience; on the other hand, a large part of it was still in many ways embedded within the nationally-focused historical perspectives of the Italian 'anomaly' or 'exception', and directly or indirectly tended to recover and consolidate previous nationalistic narratives that shaped public opinion. In conclusion, I argue that this emphasis on the 'exceptionalism' of Italian history is often the outcome of an explicit or implicit comparison with the Western historical trajectories of France and Britain, which are understood as models of 'modernity' or 'normalcy'. However, I suggest that a comparative perspective including nineteenth- and twentieth-century experiences in East Central and South-Eastern Europe might frame a better understanding of the synchronic Italian experiences and re-centre them within broader contexts.

As a starting point it is necessary to consider how and why during this uncertain political transition anti-fascism became a major source of contention in the public conversation. After 1945 the myth of the resistance was established as the official basis of democratic legitimacy of the republic for a number of reasons. Firstly, it helped to re-legitimise the national myth (discredited by its fascist uses) in the

\footnotetext{
1 Luciano Cafagna, La grande slavina: l'Italia verso la crisi della democrazia (Venezia: Marsilio, 1993), 26.

2 This crucially transitional period of recent Italian history, in many ways comparable to the East Central European transitions, has not been thoroughly studied yet: for some hints see Federico Romero and Silvio Pons, eds., L'Italia contemporanea dagli anni Ottanta a oggi, 1: La fine della guerra fredda e la globalizzazione (Roma: Carocci, 2014) and Francesco Tuccari, La rivolta della società. L'Italia dal 1989 a oggi (Roma-Bari: Laterza, 2019).

(c) The Author(s), 2021. Published by Cambridge University Press. This is an Open Access article, distributed under the terms of the Creative Commons Attribution licence (http://creativecommons.org/licenses/by/4.0), which permits unrestricted re-use, distribution and reproduction, provided the original article is properly cited.
} 
public commemoration and representation of the partisans' war as a 'war of national liberation'. Accordingly, it allowed the dualistic opposition between the 'good Italian' and the 'bad German' to form both in the public discourse and at the diplomatic level. ${ }^{4}$ Additionally, it provided the Italian Communist Party, representing the main organised force of partisans, with a powerful source of national democratic legitimacy, in spite of its structural links with the Soviet Union. Nevertheless, the different wartime experiences within Italian society, the persistent legacies of fascism and the widespread conservative conceptions of anti-communism in the highly divisive context of the Cold War meant that anti-fascism was far from being unanimously accepted. ${ }^{5}$

From the mid-1980s, when the socialist leader Bettino Craxi tried to promote a new season of constitutional reforms and delivered a harsh polemic against the Communist Party, anti-fascism became the focus of bitter public controversy. The anti-fascist public discourse, based on the myth of the resistance as the symbolic foundation of the democratic republic, was increasingly contested by the political and intellectual forces who aimed to transform the post-1945 parliamentary system into some kind of presidential system. In the 1990s the dispute around anti-fascism escalated with the rise of TV-entrepreneur Silvio Berlusconi's charismatic populism, which was imbued with anti-communism and openly challenged the anti-fascist consensus in the parliament. ${ }^{6}$

The critique and crisis of the anti-fascist paradigm emerged at a time when a new generation of post-1945 politicians and intellectuals were taking the public stage and public opinion had started to confront the unspoken, neglected or removed legacies of the Second World War. ${ }^{7}$ As a matter of fact, the foundational myth of the 'republic born out of the resistance' was based on the relationship between anti-fascism and the 'Italian nation' - namely, the very idea that the 'Italian people' had been inherently anti-fascist. This self-absolving myth was increasingly questioned by some scholars. From here stemmed a number of new (often controversial) historical questions regarding hitherto neglected or removed aspects of the attitude of Italian society and culture to the fascist regime, of the Italian role in the persecution of the Jews and in the Second World War, of the 1943-5 civil war and its violent legacies. While Italy's future was dramatically changing, its own past was changing as well. Ultimately, for historians across the historiographical spectrum, the demise of the 'republic of parties' (according to Pietro Scoppola's expression) was perceived as the shocking disappearance of a familiar world; at the same time, it was experienced as an unexpected opportunity to provide a reappraisal of the past. ${ }^{8}$

3 Guri Schwarz, Tu mi devi seppellir: riti funebri e culto nazionale alle origini della Repubblica (Torino: Utet, 2011); Leonardo Paggi, Il popolo dei morti. La Repubblica italiana nata dalla guerra (1940-1946) (Bologna: Il Mulino, 2009).

4 Filippo Focardi, ' " Bravo italiano e cattivo tedesco »: riflessioni sulla genesi di due immagini incrociate', Storia e memoria, 1 (1996), 55-83; Focardi, 'La memoria della guerra e il mito del « bravo italiano ». Origine e affermazione di un autoritratto collettivo', Italia contemporanea, 28 (2001), 393-9; Focardi, Il cattivo tedesco e il bravo italiano. La rimozione delle colpe della seconda guerra mondiale (Roma-Bari: Laterza, 2013).

5 Aurelio Lepre, L'anticomunismo e l'antifascismo in Italia (Bologna: Il Mulino, 1997); Salvatore Lupo, 'Antifascismo, anticomunismo e anti-antifascismo nell'Italia repubblicana', in Alberto De Bernardi and Paolo Ferrari, eds., Antifascismo e identità europea (Roma: Carocci, 2004), 365-78; Filippo Focardi, La guerra della memoria. La Resistenza nel dibattito pubblico italiano dal 1945 a oggi (Roma-Bari: Laterza, 2005); Giovanni De Luna, La Repubblica del dolore: le memorie di un'Italia divisa (Milano: Feltrinelli, 2011); Philip Cooke, The Legacy of the Italian Resistance (New York: Palgrave McMillan, 2011; It. ed.: Roma: Viella, 2015).

6 Mino Argentieri, Antonio Baldassarre, Guido Crainz, Marcello Flores, Nicola Gallerano, Luigi Ganapini, Mario Isnenghi, Francesco Petroni, in 'Fascismo e antifascismo negli anni della Repubblica', Problemi del socialismo, 7 (1986); Remo Bodei, Il noi diviso: ethos e idee dell'Italia repubblicana (Torino: Einaudi, 1998); Sergio Luzzatto, Crisi dell'antifascismo (Torino: Einaudi, 2004).

7 For a European contextualisation see Tony Judt, 'The Past Is Another Country: Myth and Memory in Postwar Europe', Daedalus, 121 (Fall 1992), 83-118, now in Jan-Werner Müller, ed., Memory and Power in Post-war Europe: Studies in the Presence of the Past (Cambridge: Cambridge University Press, 2002), 157-83.

8 While Paul Ginsborg's book was published before the turning point of 1989-1992, other important histories of the Italian Republic were conceived and issued in its aftermath: see Paul Ginsborg, Storia d'Italia dal dopoguerra a oggi: società e politica, 1943-1988 (Torino: Einaudi, 1989); Pietro Scoppola, La Repubblica dei partiti: profilo storico della democrazia in Italia, 1945-1990 (Bologna: Il Mulino, 1991); Silvio Lanaro, Storia dell'Italia repubblicana: dalla fine della guerra 


\section{Historians as 'Engineers of Italianness'?}

In many ways the historical narratives of the early 1990s drew on patterns of Italian 'anomaly' or 'exception' which had already circulated in the previous decades. In a seminal and influential essay included in the Storia d'Italia published by Einaudi in 1972, the editor and intellectual Giulio Bollati investigated the 'national character as history and as an invention', with the intention of understanding the role and projects of the 'engineers of Italianness' from the late eighteenth century onward. As it turned out, Italianness was fashioned by a reluctant, even hostile attitude towards modernity, and especially industrial and urban modernity. ${ }^{9}$ In the early 1980 s scholars from different positions investigated flaws and weaknesses of Italian nation building. Silvio Lanaro, a leftist historian of nationalism, called attention to the structural absence of a unifying centre, underscoring the persistent force of 'polycentrism' as a key feature for framing the pathological shortcomings of Italian modernisation and nationalisation. ${ }^{10}$ On a different note, Rosario Romeo, a liberal scholar of the Risorgimento, outlined a long-term historical survey of the Italian nation, one in which the tragic impact of the Second World War on the decline of the nation state was already considered. ${ }^{11}$

As the ensuing debates and researches showed, the limits of the Italian state and nation building emerged particularly with close scrutiny of the Second World War and of the 1943-5 conflicts. As the historian Claudio Pavone made increasingly clear, far from being a 'Second Risorgimento' (as the official rhetoric claimed), the resistance (Resistenza) entailed an opposition between different ideas of the Italian nation and a contest between different legacies of the Risorgimento. In the first half of the 1980s Pavone started to write up his research about the 'civil war' between fascists and antifascists. ${ }^{12}$ In 1991 the publication of A Civil War shattered a still broad historiographical consensus around the resistance as a 'war of national liberation'. Pavone offered a deep revision of this monolithic interpretation and unpacked it into the idea of the 'three wars': the war of national liberation, the civil war and the class war. The 'three wars' were the key not only for understanding the political, cultural and social complexities of the 1943-5 period but also for investigating the actors' (especially partisans') subjective intentions and identifications. Therefore, rather than dealing with the role of the political parties in the resistance, as most of the previous scholarship did, Pavone's book addressed individuals' 'morality', that is their choices vis-à-vis the dramatic alternatives following the collapse of the state authorities after the official announcement of the armistice between Italy and the allied coalition on 8 September 1943. Although Pavone's interpretative pattern was based on the 'three wars', his idea of the 'civil war' especially contributed to questioning well-established national narratives of the resistance. Until then, the definition of 'civil war' that was applied to the period 1943-5 had been mostly claimed by neo-fascists, who tried to legitimise themselves as a credible national force even after the defeat of Mussolini's regime. However, Pavone's idea of a 'civil war' between fascists and anti-fascists had been a mostly neglected and marginal tradition springing from the noncommunist, but leftist group of the Partito d'Azione (1942-7). ${ }^{13}$

agli anni Novanta (Venezia: Marsilio, 1992); Aurelio Lepre, Storia della prima Repubblica: l'Italia dal 1942 al 1992 (Bologna: Il Mulino, 1993).

9 Giulio Bollati, L'italiano: il carattere nazionale come storia e come invenzione (Torino: Einaudi, 1996 [1983]), 9. This was originally published as 'L'Italiano', in Storia d'Italia. I: I caratteri originali (Torino: Einaudi, 1972), 952-1022. On the critical importance of this text and of the Storia d'Italia published by Einaudi more generally for the development of narratives based on the idea of the Italian 'exceptionalism' see Francesco Benigno and Igor Mineo, eds., L'Italia come storia. Primato, decadenza. eccezione (Roma: Viella, 2020).

10 See Silvio Lanaro, Italia nuova. Identità e sviluppo, 1861-1988 (Torino: Einaudi, 1988), but also his earlier work Lanaro, Nazione e lavoro. Saggio sulla cultura borghese in Italia, 1870-1925 (Venezia: Marsilio, 1979).

11 Rosario Romeo, Italia mille anni (Firenze: Le Monnier, 1981), 175.

12 His first public intervention on the topic was delivered at a conference in Brescia on 4-5 October 1985: see Claudio Pavone, 'La guerra civile', in Pierpaolo Poggio, ed., 'La Repubblica sociale italiana 1943-45', Annali della Fondazione Luigi Micheletti, 2 (Brescia: Fondazione L. Micheletti, 1986), 395-415.

13 Claudio Pavone, Una guerra civile: saggio sulla moralità nella Resistenza (Torino: Bollati Boringhieri, 1991; Eng. ed.: London-New York: Verso, 2013). For a first overview of his intellectual path see Guri Schwarz, 'The Moral Conundrums of an Historian: Claudio Pavone's A Civil War and Its Legacy', Modern Italy, 20, 4 (2015), 427-37; 
At the heart of Pavone's book lay some critically path-breaking questions: 'what had been defeated in the fascist war fought between the 1940 and 1943? Only fascism? Or the Italian state with which fascism had identified itself? Or even more Italy itself, as a historically defined national entity? ${ }^{14}$ Questions of this sort were taken up and discussed at a conference held in Trieste in September 1993, to mark the fiftieth anniversary of the Italian armistice with the allied coalition and subsequent crisis of September 1943. On that occasion the historian and publicist Ernesto Galli della Loggia presented a first draft of his reflection on the 'death of the nation', which he then developed into a controversial book in 1996. By taking for granted the self-alleged identification of fascism and nation, della Loggia argued that the breakdown of the fascist regime entailed a 'crisis of the idea of nation' and raised a 'radical question about identity', about 'the very possibility that Italians are a nation'. Pavone firmly distinguished the fascist regime and the Italian nation state and accordingly the backlash of the collapse of the former on the latter. According to della Loggia, instead, the military defeat of 1943 had not only overthrown Mussolini's dictatorship but had also eroded loyalty to the nation state as such. ${ }^{15}$ By contrast, the historian Lanaro directly linked the delegitimisation of nationalism in the post-1945 public discourse to its previous fascist uses. Notably, he complained that anti-fascist democracy had been marked by the indifference to the concept of nation ... in the conviction that the name and the very idea of Italy have been irreparably tampered with by fascism. ${ }^{16}$ Surely, the legacies of the fascist experience had discredited nationalism as well as imperialism, banning them from the open public discourse after 1945. However, the nationalist language and the representation of the nation, far from disappearing in the long post-war period, were subject to deep transformations and adaptations to the context of economic development and the ideological division of the Cold War. ${ }^{17}$ The political scientist Gian Enrico Rusconi and the historian Pietro Scoppola questioned della Loggia's identification of the collapse of the fascist regime with the 'death of the nation' and claimed an autonomous patriotic value to the anti-fascist democratic tradition, while interpreting it in different forms, respectively secular and Catholic. ${ }^{18}$

In retrospect it is clear that the mass parties that established themselves after 1945 had been the main agents of political participation and social transformation, but their crisis in the 1990s exposed what was perceived and experienced as a lack of collective belonging, of civic spirit, of national identification. Meanwhile, the uncertain transition of the early 1990s threw into doubt the unity of the nation state itself. Notably, the rise of the Northern League (Lega Nord) fluctuated between federalist positions and secessionist ones, while the proximity of the Yugoslav wars made scenarios of institutional disintegration more credible. In the face of the localist radicalism of the Lega Nord, several historians internalised the role of nation builders or 'engineers of Italianness', and elaborated arguments that were deemed to offer new legitimacy to the nation state. By drawing on the philosopher Jürgen Habermas's well-known reflection about the civic foundations of the Western German democracy, Rusconi supported the need for a 'patriotic constitutionalism' as a solution to the loss

Marcello Flores, ed., Mestiere di storico e di cittadino. Claudio Pavone e la storia contemporanea in Italia (Roma: Viella, 2019), and the monographic number dedicated to Claudio Pavone of Parolechiave, 61, 1-2 (Dec. 2019).

14 Pavone, Una guerra civile, 169.

15 Ernesto Galli della Loggia, 'La morte della patria. La crisi dell'idea di nazione dopo la seconda guerra mondiale', in Giovanni Spadolini, ed., Nazione e nazionalità in Italia. Dall'alba del secolo ai nostri giorni (Roma-Bari: Laterza, 1994), 125-61; Galli della Loggia, La morte della patria. La crisi dell'idea di nazione fra Resistenza, antifascismo e Repubblica (Roma-Bari: Laterza, 1996). A deeply researched essay on 'a nation in disarray' in the aftermath of 8 September 1943 was provided by Elena Aga-Rossi, Una nazione allo sbando. L'armistizio italiano del settembre 1943 e le sue conseguenze (Bologna: Il Mulino, 1993; 2nd ed., 2003; Eng. ed.: Cambridge: Cambridge University Press 2000).

16 Lanaro, Storia dell'Italia repubblicana, 18.

17 Franco De Felice, 'Nazione e sviluppo: un nodo non sciolto', in Francesco Barbagallo, ed., Storia dell'Italia repubblicana, (Torino: Einaudi, 1995), II: Le trasformazioni dell'Italia: sviluppo e squilibri, 2. Economia e società, and De Felice, 'Nazione e crisi: le linee di frattura', in Barbagallo, ed., Storia dell'Italia repubblicana, III. L'Italia nella crisi mondiale. L'ultimo ventennio, 1:. Economia e società (Torino: Einaudi, 1996). Franco De Felice was not a relative of Renzo De Felice.

18 Gian Enrico Rusconi, Resistenza e postfascismo (Bologna: Il Mulino, 1995); Pietro Scoppola, 25 aprile: liberazione (Torino: Einaudi, 1995). 
of legitimacy of the Italian state. Vis-à-vis the limits of anti-fascism as common ground for democratic citizenship, only the constitution might provide for the republic a kind of 'civic religion'. ${ }^{19}$ Conversely, a leftist scholar like Mario Isnenghi spilled much ink to rewrite narratives of Italian history and of its national myths and memories in harsh disagreement against any secessionist argument from the Lega Nord. Renowned for his critical analysis of the 'myth of the Great War' in the 1970s, he later changed direction and embraced a national stance between the late 1990s and the $2000 \mathrm{~s}^{20}$

The crisis of the early 1990s thus brought to the surface much older national/nationalist narratives. Some of them posited the existence of 'Italians without Italy' and the very long continuity of 'Italian identity' over the centuries (from the Roman times onward). This position implied a kind of antihistorical approach, based on a widespread use of stereotypes about 'Italians', allegedly existing well before the start of Italian state and nation building. ${ }^{21}$ Others framed more subtle arguments such as the typically 'Italian' primacy of private interests and of particular divisions in order to explain the absence of a sense of national community or the lack of a nation state. ${ }^{22}$ The $150^{\text {th }}$ anniversary of the 'unity of Italy' (2011), despite the official rhetoric, fuelled the narrative of Italy as 'neither state nor nation', complaining of the absence of a 'civic religion', without changing the overall sense of the typical public conversation from the 1990s onward. ${ }^{23}$ As Silvana Patriarca explained, grievances over the lack of national identity drew on a long tradition of Italian nineteenth- and twentiethcentury narratives and were part and parcel of the national/nationalist narratives. While exclusively, and somewhat obsessively, focusing on the 'national character', they crystallised themselves in a selfreferential discourse about 'Italian vices' that endlessly replicated the cultural and anthropological stereotypes about 'Italy' and 'Italians'. ${ }^{24}$

\section{Fascism, Nationalism and the Legacy of Risorgimento}

The critique of the anti-fascist paradigm in its moment of crisis paved the way for a new understanding of fascism. The myth of the 'anti-fascist nation', upon which the republic had drawn, had helped to erase, remove, forget and marginalise the connections and entanglements between the fascist regime and Italian society and culture. At the core of Italian contemporary history since the 1960s was the path-breaking and controversial work by Renzo De Felice, author of a monumental biography of Mussolini. He resorted to the biographical lens of the 'duce' as the main way to understand the entire

19 Gian Enrico Rusconi, Se cessiamo di essere una nazione. Tra etnodemocrazie regionali e cittadinanza europea (Bologna: Il Mulino, 1993); Rusconi, Patria e repubblica (Bologna: Il Mulino, 1997); Rusconi, Possiamo fare a meno di una religione civile? (Roma-Bari: Laterza, 1999).

20 Mario Isnenghi, Breve storia dell'Italia unita a uso dei perplessi (Milano: Rizzoli, 1998); Isnenghi, Dieci lezioni sull'Italia contemporanea: da quando non eravamo ancora nazione ... a quando facciamo fatica a rimanerlo (Roma: Donzelli, 2011); Isnenghi, Storia d'Italia: fatti e percezioni dal Risorgimento alla società dello spettacolo (Roma-Bari: Laterza, 2011).

21 Aldo Schiavone, Italiani senza Italia. Storia e identità (Torino: Einaudi, 1998); Ernesto Galli della Loggia, L'identità italiana (Bologna: Il Mulino, 1998).

22 Walter Barberis, Il bisogno di patria (Torino: Einaudi, 2004). For a general account of these debates see Paolo Pezzino, Senza Stato: le radici storiche della crisi italiana (Roma-Bari: Laterza, 2002).

23 Emilio Gentile, Né stato né nazione: italiani senza meta (Roma-Bari: Laterza, 2010); Giovanni De Luna, Una politica senza religione (Torino: Einaudi, 2013). A balance sheet of the nationalising project under the republic was provided by Silvio Pons, ed., Farsi italiani: la costruzione dell'idea di nazione nell'Italia repubblicana (Milano: Feltrinelli, 2011). On the occasion of the $150^{\text {th }}$ anniversary of the 'unity of Italy', an exhibition entitled Fare gli italiani. 150 anni di storia nazionale was organized in Turin (Officine Grandi Riparazioni, 17 Mar.-20 Nov. 2011) under the supervision of Walter Barberis and Giovanni De Luna. For a critical review of the nationally-focused approach to the Italian history see Maurizio Bertolotti, 'Fare gli italiani. 150 anni in mostra', Passato e presente, 86 (2012), 95-106.

24 Alessandro Cavalli, 'Reflections on Political Culture and the 'Italian National Character', Daedalus, 130 (2001), 119-37; Silvana Patriarca, 'Italian Neopatriotism: Debating National Identity in the 1990s', Modern Italy, 6 (2001), 21-34; Patriarca, Italianità. La costruzione del carattere nazionale (Roma-Bari: Laterza, 2010; Eng. ed.: Cambridge, Mass.: Cambridge University Press, 2010); Loreto Di Nucci, Ernesto Galli della Loggia, eds., Due nazioni. Legittimazione e delegittimazione nella storia dell'Italia contemporanea (Bologna: Il Mulino, 2003). 
history of fascism both as a 'movement' and a 'regime. ${ }^{25}$ Here it is not possible to discuss in detail his extraordinarily rich archival research and his often contradictory positions in historical interpretation. His focus on the leftist, revolutionary origins of Mussolini's political career, as well as on the 'consensus' of Italian society with the fascist regime were the most divisive sources of polemic against him. ${ }^{26}$ De Felice's work targeted an image of fascism based on the anti-fascist tradition, denying any enduring popularity within Mussolini's regime and emphasising its differences from Hitler's Nazi regime. With the change of the political and cultural mood in the 1980s, which increasingly shifted away from the centrality of anti-fascism in the public and political discourse, De Felice proclaimed himself, and was understood as, the pioneer and main interpreter of 'revisionism'. In retrospect, the polemical label of 'revisionist' or 'revisionism' was a rhetorical devise for legitimising or delegitimising historians or historical works which were supposed to go beyond the anti-fascist paradigm. De Felice questioned the anti-fascist 'vulgate', exacerbating the dualistic representation of the civil war between the 'reds' and the 'blacks' and overstressing the role of the communists in the resistance. ${ }^{27}$

In many ways the problem of the 'consensus' behind fascism was taken up by Emilio Gentile, who had collaborated with Renzo De Felice and George Mosse, and who, since the mid-1970s, had incessantly studied the political ideology of fascism, as well as the myth of the 'new state' in early twentiethcentury Italian culture. His focus then shifted to the 'sacralisation of politics', that is the elaboration and implementation of the fascist 'political religion', while considering the innovative role of the 'militia-party' and of its totalitarian function. ${ }^{28}$ At the already mentioned conference of Trieste, Gentile presented a paper on the 'origins of the decline of the nation state'. In his opinion, this decline was inherent in a fascist conception of the idea of nation, on which the imperial project of a new European order during the Second World War was based. ${ }^{29}$ This theme was then developed in the work La Grande Italia (1997), in which Gentile came to define fascism as 'the implementation of an anthropological revolution, to regenerate the Italians, "to remake" their character, to create a new spiritual and racial identity of the nation'. In the context of the discussions of the 1990s Gentile tended to identify the common core of feelings, ideas, myths and values of the nation and at the same time to critically separate nationalism, imperialism and fascism, articulating the profound differences in the political uses of the national myth. ${ }^{30}$

Gentile was the first scholar to systematically study the language and political culture of nationalism and its relationship with fascism, while acknowledging that nationalism was perfectly consistent with anti-fascism as well. In this respect he still posited himself within a framework that was based on the opposition between Italian patriotism and German nationalism and was theorised by Federico Chabod, who had been a scholar under the fascist regime and a partisan in the Italian resistance. According to Chabod, the idea of the Italian nation was based on free will, conscience and culture (on the model of Ernest Renan's conception of the French nation as 'an everyday plebiscite'), whereas the idea of the German nation was grounded on ethnicity and race. Accordingly, the former was potentially consistent with anti-fascism and liberalism, and the latter was inherently nationalist and racist. ${ }^{31}$

\footnotetext{
25 For his intellectual biography see Paolo Simoncelli, Renzo De Felice: la formazione intellettuale (Firenze: Le Lettere, 2001) and Emilio Gentile, Renzo De Felice: lo storico e il personaggio (Roma-Bari: Laterza, 2003).

26 See notably Renzo De Felice, Mussolini il rivoluzionario, 1883-1920 (Torino: Einaudi, 1965) and De Felice, Mussolini il duce: gli anni del consenso, 1929-1936 (Torino: Einaudi, 1974); but a strong public impact had De Felice's interview edited by Michael Leeden, Intervista sul fascismo (Roma-Bari: Laterza, 1975).

27 Renzo De Felice, Il rosso e il nero, edited by Pasquale Chessa (Milano: Baldini\&Castoldi, 1995). This interview was an anticipation of his volume La guerra civile, 1943-1945, third part of Mussolini l'alleato, 1940-1945 (Torino: Einaudi, 1997), which was published incomplete and posthumous, as De Felice died in 1996.

28 Emilio Gentile, Il culto del littorio. La sacralizzazione della politica nell'Italia fascista (Roma-Bari: Laterza, 1993; Eng. ed.: Cambridge, Mass.: Cambridge University Press, 1996); Gentile, La via italiana al totalitarismo. Il partito e lo Stato nel regime fascista (Roma: NIS, 1995).

29 Emilio Gentile, La nazione del fascismo. Alle origini del declino dello stato nazionale in Spadolini, ed., Nazione e nazionalità in Italia, 65-124.

30 Emilio Gentile, La grande Italia. Ascesa e declino del mito della nazione nel ventesimo secolo (Milano: Mondadori, 1997).

31 Federico Chabod, L'idea di nazione (Bari: Laterza, 1961).
} 
A completely different perspective was developed by Alberto M. Banti, a scholar from the social history tradition who moved to writing cultural history in the second half of the 1990s. As a student of nineteenth-century history, he should not be included in this Spotlight, devoted as it is to the historiography on the twentieth century. However, his challenging revision of the traditional conceptions of Italian nation building had, and still has an impact on the scholarship about twentieth-century nationalism and fascism. Banti's most radically innovative contribution was to re-read the so-called 'canon of the Risorgimento', by deconstructing the discursive formations of the national-patriotic language which shaped Italy's 'imagined community' (in Benedict Anderson's well-known expression). In his 2000 book he analysed what he called the 'profound figures of national discourse', i.e. images, representations and narratives that account for the conceptual system of nationalism, which concerned the 'primary facts' of existence as life / death, love / hate, sexuality / reproduction and which are articulated in the conception of the nation as a family, as a community of sacrifice and as a male hierarchical body. ${ }^{32}$ In a later work, Sublime madre nostra, published on the occasion of the $150^{\text {th }}$ anniversary of the 'unification of Italy', Banti argued for the morphological continuity of the representation of the Italian nation between Risorgimento, liberal Italy and fascism. Of course, he recognised that the Great War had reactivated and radicalised the 'impressive performative force' of the national-patriotic discourse. However, Banti's historical reconstruction did emphasise the sense of continuity between the nineteenth-century rhetoric of nation and the fascist discourse. ${ }^{33}$

In spite of its divisive reception Banti's work had a major impact on the current research on Risorgimento, but so far has only marginally affected historians of the twentieth century. Instead Emilio Gentile in many ways pushed scholarship to better investigate the relationship between nationalism and fascism; to cope with the ambivalent (both democratic and authoritarian) legacies of Mazzini's political culture, imagery and myth and to carefully account for divergences and convergences between the nationalist and fascist movements (at least until 1923, because studies have stopped here for now).$^{34}$ However, Emilio Gentile's approach to the fascist 'political religion', and notably the issue of a 'consensus' driven by Mussolini's dictatorship, has been subject to thorough discussions and revisions. A number of important scholars (among others, Salvatore Lupo, Richard Bosworth, Christopher Duggan, Patrizia Dogliani and Paul Corner) analysed the contradictory dynamics of fascist totalitarian politics, explored everyday life in the Ventennio, stressed the limits and conflicts of the 'popular opinion' in the local branches of the Fascist National Party and focused on the diverse, heterogeneous spectrum of the Italians' attitudes towards Mussolini's dictatorship. ${ }^{35}$ New perspectives on the social and political history of the fascist regime thus provided important complements to Gentile's path-breaking approach to cultural and ideological practices of nationalism and fascism.

32 Alberto M. Banti, La nazione del Risorgimento. Parentela, santità e onore alle origini dell'Italia unita (Torino: Einaudi, 2000). In spite of his deep and divisive impact on Italian historiography, Banti's work has had a limited influence on international scholarship so far. For a broad discussion, involving Lucy Riall, Axel Körner, David Laven, Maurizio Isabella, Catherine Brice and John Breuilly, see the Forum, 'Alberto Banti's Interpretation of Risorgimento Nationalism', in Nations and Nationalism, 15 (2009), 396-460.

33 Alberto M. Banti, Sublime madre nostra. La nazione italiana dal Risorgimento al fascismo (Roma-Bari: Laterza, 2011).

34 See Adriano Roccucci, Roma capitale del nazionalismo (1908-1923) (Roma: Archivio Guido Izzi, 2001); Elena Papadia, Nel nome della nazione. L'Associazione Nazionalista Italiana in età giolittiana (Roma: Archivio Guido Izzi, 2006); Simon Levis Sullam, L'apostolo a brandelli. L'eredità di Mazzini tra Risorgimento e fascismo (Roma-Bari: Laterza, 2010; Eng. ed.: New York: Palgrave, 2015); Catia Papa, L'Italia giovane dall'Unità al fascismo (Roma-Bari: Laterza, 2013); Paola S. Salvatori, ed., Nazione e anti-nazione, 1 : Il movimento nazionalista da Adua alla guerra di Libia (1896-1911) (Roma: Viella, 2014); Salvatori, ed., Nazione e anti-nazione, 2 : Il movimento nazionalista dalla guerra di Libia al fascismo (1911-1923) (Roma: Viella, 2016).

35 Salvatore Lupo, Il fascismo. La politica in un regime totalitario (Roma: Donzelli, 2000); Richard J.B. Bosworth, Mussolini's Italy: Life Under the Dictatorship, 1915-1945 (Penguin Books, 2005; It. ed.: Milano: Mondadori, 2007); Giulia Albanese and Roberta Pergher eds., In the Society of Fascists: Acclamation Acquiescence, and Agency in Fascist Italy (New York: Macmillan, 2012); Paul Corner, The Fascist Party and Popular Opinion in Mussolini's Italy (New York: Oxford University Press, 2012; It. ed.: Roma: Carocci, 2015); Christopher Duggan, Fascist Voices: An Intimate History of Mussolini's Italy (London: Bodley Head, 2012); Patrizia Dogliani, Il fascismo degli italiani. Una storia sociale (Torino: Utet, 2014). 
However, what generally seems to still be lacking is a broader reconstruction of the relationship between the long-term legacies of Italian state and nation building and the rise and development of the fascist experiment within the dynamic European contexts of the interwar period. In this regard, the new transnational perspectives on fascism and para-fascism and their interconnections and entanglements might shed a new light on the Italian case study. ${ }^{36}$

\section{Critique of the 'Myth of the Good Italian' (and Beyond)}

In the late 1980s, in contrast to Historikerstreit-era West Germany, Italian public opinion was far from coming to grips with some of the most tragic and controversial aspects of the fascist experience. Nevertheless, a critical reflection by the essayist David Bidussa tried to shake up the obstinate 'myth of the good Italian' (mito del bravo italiano). The 'Italians' had long considered themselves as intrinsically unable to commit war crimes and crimes against humanity, discrimination and intolerance. As a consequence the post-1945 public memory had removed or forgotten the Italian role in the discrimination and persecution of the Jews under the fascist regime after 1938 and in the Social Republic of Salò (1943-5), as well as the deep traditions of racism and anti-Semitism in Italian society and culture. Bidussa argued that at the root of the 'myth of the good Italian' laid a 'national character' forged by the mixture of 'ancient' and 'modern' elements and therefore unwilling to establish a 'virtuous' relationship between state and civil society. As controversial as this approach still based on 'national character' may be, Bidussa's critical analysis of this myth was able to question the widespread tendency for self-absolution of Italian public opinion and the subsequent indulgence towards its own history of violence. Most of the new wave of studies on racism and anti-Semitism, as well as on imperialism, was in one way or another inspired by Bidussa's critical reassessment of the 'myth of the good Italian'.

This new interest in racism and anti-Semitism took shape at a moment when Italian society was losing its culturally and religiously homogeneous nature, and when a backlash of intolerance against North African immigrants became impossible to ignore. This new historiographical turn took aim at De Felice's argument, according to which Italy had remained essentially free from anti-Semitism and racism, with the racial legislation of 1938 and anti-Jewish persecution merely the consequence of the alliance with Nazi Germany. In De Felice's view, Mussolini's concept of race was understood 'in a "creative" and "spiritualist" way that had nothing to do with anthropology and biology'. ${ }^{38}$ In the context of the Historikerstreit - the harsh mid 1980s debate among the German historians over the relations between Nazism and Soviet Communism, between Auschwitz and Kolyma - De Felice thus tended to acquit Italian fascism from responsibilities in the Shoah. In opposition to De Felice's stance was the catalogue of an exhibition that was held in Bologna in 1994 and entitled $\mathrm{La}$ menzogna della razza. At the centre of this new vision was the conviction that fascist racism, rather than being a compact and coherent block, was a set of different cultural currents and conceptions: 'biological racism', 'national-racism', 'traditional-esoteric racism'. ${ }^{39}$ A new generation of scholars has recently paid attention to the role of culture and science in the development of fascism and

36 See, in general, António Costa Pinto, Aristotle Kallis, eds., Rethinking Fascism and Dictatorship in Europe (Basingstoke: Palgrave Macmillan, 2014); Arnd Bauerkämper, Grzegorz Rossoliński-Liebe, eds., Fascisms without Borders: Transnational Connections and Cooperation between Movements and Regimes in Europe from 1918 to 1945 (New York: Berghahn Books, 2017).

37 David Bidussa, 'Razzismo e antisemitismo in Italia: fenomenologia e ontologia del bravo italiano', Rassegna Mensile di Israel, 3 (1992), 1-36 and Bidussa Il mito del bravo italiano (Milano: Il Saggiatore, 1994). For a synthesis of this debate see also Guri Schwarz, 'Un cambio di paradigma: considerazioni sulla decostruzione del "mito del bravo italiano»', in Michele Battini and Guri Schwarz, eds., San Rossore 1938. Contro gli ebrei (Pisa: Pisa University Press, 2019), $227-47$.

38 Renzo De Felice, 'La legislazione razziale del fascismo', in La legislazione antiebraica in Italia e in Europa, Proceedings of the conference in the $50^{\text {th }}$ anniversary of the racial laws (Rome, 17-18 Oct. 1988) (Roma: Edizioni della Camera dei Deputati, 1989), 11-5; De Felice, Storia degli ebrei italiani sotto il fascismo (Torino: Einaudi, 1993) [or. ed. 1961 ], 256.

39 Mauro Raspanti, 'I razzismi del fascismo', in Centro Furio Jesi, ed., La menzogna della razza. Documenti e immagini del razzismo e dell'antisemitismo fascista (Bologna: Grafis, 1994), 73-89; Raspanti, Le correnti del razzismo fascista in Anna 
anti-Semitism, to the influence of the Catholic tradition of anti-Judaism, to the practices of discrimination and persecution of Mussolini's regime, to the connections between anti-Slavism and racism and to the impact of colonial legislation on racial legislation. ${ }^{40} \mathrm{~A}$ real historiographical turn from De Felice's approach has followed, which has stressed the autonomous cultural roots and political initiatives of fascist anti-Semitism and racism.

Since the early 1990s fascist studies have been deeply reframed by women's history, gender history and body history with the aim of integrating political and ideological history with the analysis of deeper, underlying cultural patterns. In Italy as elsewhere Mosse's pioneering work on masculinity and nationalism had a great influence, while Banti's work about the 'honour of the nation' paved the way for a new interpretation of sexuality and nationalism. ${ }^{41}$ Victoria De Grazia paid a new attention to women's everyday role and mentality under the fascist regime and their ambivalent attitudes between impulses to modernisation and desires of restoration, while Giovanni De Luna explored women's participation in anti-fascist networks and their contribution to the search for a new politics. ${ }^{42}$ A fresh look at fascist uses of mass media communication and its integrally male representation system allows a new understanding of the 'modernity' of Mussolini's regime. ${ }^{43}$ Further works then highlighted the virile, warlike stereotypes within fascist cultural and social practices and connected them to broad (often too broad) cultural and anthropological patterns. ${ }^{44}$ Additionally, Sergio Luzzatto provided an innovative take on the political and religious imaginaries of twentieth-century Italy, focusing on 'Duce' Benito Mussolini and on Padre Pio, the Catholic saint object of a truly Italian, yet globally widespread, devotion. Rather than focusing on political religions, as Gentile did, Luzzatto mixed cultural and body studies and detected the deep effects of these charismatic figures and of their performances in terms of intertwining between politics and religion. ${ }^{45}$

Closely related to the research agenda about racism was the new interest in fascist imperialism. Obviously, there was no lack of pioneering efforts to come to terms with the experiences of Italian colonialism in Libya and East Africa, with the wars of imperial conquest in Yugoslavia and with fascist

Capelli and Renata Broggini, eds., Antisemitismo in Europa negli anni Trenta. Legislazioni a confronto (Milano: Franco Angeli, 2001), 238-51.

40 See Giorgio Israel, Pietro Nastasi, Scienza e razza nell'Italia fascista (Bologna: Il Mulino, 1998); Alberto Burgio, ed., Nel nome della razza: il razzismo nella storia d'Italia, 1870-1945 (Bologna: Il Mulino, 1999); Roberto Maiocchi, Scienza e fascismo (Roma: Carocci, 2004); Francesco Cassata, 'La Difesa della Razza'. Politica, ideologia e immagine del razzismo fascista (Torino: Einaudi, 2008); Cassata, Building the New Man. Eugenics, Racial science and Genetics in Twentieth Century Italy (Budapest, New York: Central European University Press, 2011); Marie-Anne Matard- Bonucci, L'Italia fascista e la persecuzione degli ebrei (Bologna: Il Mulino, 2008); Marcello Flores, Simon Levis Sullam, Marie-Anne Matard-Bonucci and Enzo Traverso, eds., Storia della Shoah in Italia: vicende, memorie, rappresentazioni (Torino: UTET, 2010); Michele Sarfatti, Gli ebrei nell'Italia fascista. Vicende, identità, persecuzione (Einaudi: Torino 2018; ed. or. 2000); Simon Levis Sullam, I carnefici italiani: Scene dal genocidio degli ebrei, 1943-1945 (Milano: Feltrinelli, 2015; Eng. ed.: Princeton, Princeton University Press, 2018); Valeria Galimi, 'Sotto gli occhi di tutti'. La società italiana e le persecuzioni contro gli ebrei (Firenze: Le Monnier, 2018).

41 George Mosse, Nationalism and Sexuality: Respectability and Abnorm Sexuality in Modern Europe (New York: Howard Fertig, 1985); Alberto M. Banti, L'onore della nazione. Identità sessuali e violenza nel nazionalismo europeo dal 18. secolo alla grande guerra (Torino: Einaudi, 2005).

42 Victoria De Grazia, How Fascism Ruled Italian Women, 1922-1945 (Berkeley: University of California Press, 1992); Giovanni De Luna, Donne in oggetto. L'antifascismo nella società italiana, 1922-1943 (Torino: Bollati Boringhieri, 1995).

43 See for instance Ruth Ben Ghiat, La cultura fascista (Bologna: Il Mulino, 2000; English ed.: Berkeley: University of California Press, 2001); Ben Ghiat, 'Unmaking the Fascist Man: Masculinity, Film, and the Transition from Dictatorship', Journal of Modern Italian Studies, 10 (2005), 336-65.

44 Lorenzo Benadusi, Il nemico dell'uomo nuovo. L'omosessualità nell'esperimento totalitario fascista, preface of Emilio Gentile (Milan: Feltrinelli, 2005); Sandro Bellassai, L'invenzione della virilità. Politica e immaginario maschile nell'Italia contemporanea (Roma: Carocci, 2011). For a critical overview see Benadusi, 'Storia del fascismo e questioni di genere', Studi storici, 1 (Jan.-Mar. 2014), 183-95.

45 Sergio Luzzatto, Il corpo del Duce: un cadavere tra immaginazione, storia e memoria (Torino: Einaudi, 1998; Eng. ed. Metropolitan Books, 2005); Luzzatto, Padre Pio. Miracoli e politica nell'Italia del Novecento (Torino: Einaudi, 2006; Eng. ed. Metropolitan Books, 2010). 
repression from outside the national context. ${ }^{46}$ However, it is only since the 1990 s that the repressive policies against civilian populations and war crimes carried out by the Italian army have begun to be deeply investigated. A completely new framework has superseded that of the 'ragged' imperialism (imperialismo straccione) that once circulated as a correlative of the myth of the 'Italians, good people' (Italiani, brava gente). ${ }^{47}$ In this historiographical perspective the Ethiopian war of 1935-6 was considered as a crucial part of fascist empire building. Accordingly a new focus concentrated on the brutal methods of colonial rule, as well as on the massacres against the local populations of Italian Eastern Africa. ${ }^{48}$ Meanwhile, a new interest developed in exploring the fascist Mediterranean order in 1940-3, with particular attention paid to the practices of military occupation and repression of civilian populations in the Balkans and to the war crimes in occupied Yugoslavia and Greece. ${ }^{49}$ For sure, more traditional works still focused on the imperial conquest of the Adriatic, as well as on the fascist geopolitical strategies concerning central Europe and the Balkans. ${ }^{50}$ However, and more importantly, rather than relating imperialism to fascist foreign policy or to capitalist interests, other scholars acknowledged the importance of empire building as part and parcel of the fascist culture and imagery and inquired into the ways in which the fascist regime imposed its authority on disputed borderlands (and beyond them). ${ }^{51}$

Much research is still needed to reconstruct the long-term cultural roots of twentieth-century nationalism, fascism, racism, anti-Semitism and imperialism, one that can highlight a repertoire of cultures and practices on the scale of the European-wide circulation. However, what is telling here is that, in spite of the significant progress made in terms of archival work and interpretative complexity, these studies had a marginal impact on a large national audience. As a matter of fact, no public exhibition or museum nor official remembrance day is devoted to either the Italian responsibility for persecutions of minorities or the crimes of the fascist wars. Quite the contrary. A new public memory has recently emerged - one representing the 'Italians' among the 'victims' of the Second World War. ${ }^{52}$

\section{From the Edge of the 'Nation'}

Within the framework of European public memories of the Second World War, events which didn't match the image of the 'anti-fascist war' ended up being silenced, forgotten, removed or minimised in

46 The pioneering study of the Italian fascist colonialism in Africa was carried out by Angelo Del Boca: among his several works, see, for instance, La guerra d'Abissinia, 1935-1941 (Milano: Feltrinelli, 1965); Gli italiani in Africa orientale, 4 voll. (Roma-Bari: Laterza, 1976-1986); Gli italiani in Libia, 2 voll. (Roma-Bari: Laterza, 1986); L'Africa nella coscienza degli italiani. Miti, memorie, errori, sconfitte (Roma-Bari: Laterza, 1992); I gas di Mussolini: il fascismo e la guerra d'Etiopia (Roma: Editori Riuniti, 1996).

47 Angelo Del Boca, Italiani, brava gente? (Vicenza: Neri Pozza, 2005)

48 See Nicola Labanca, Oltremare. Storia dell'espansione coloniale italiana (Bologna: Il Mulino, 2002); Riccardo Bottoni, ed., L'impero fascista. Italia ed Etiopia (1935-1941) (Bologna: Il Mulino, 2008); Matteo Dominioni, Lo sfascio dell'Impero: gli italiani in Etiopia, 1936-1941 (Roma-Bari: Laterza, 2008); Emanuele Ertola, In terra d'Africa. Gli italiani che colonizzarono l'impero (Roma-Bari: Laterza, 2017).

49 Davide Rodogno, Il nuovo ordine mediterraneo: le politiche di occupazione dell'Italia fascista in Europa, 1940-1943 (Torino: Bollati Boringhieri, 2003; Eng. ed.: Cambridge, Mass.: Cambridge University Press, 2006).

50 H. James Burgwyn, Fascist Foreign Policy in Interwar Period, 1918-1940 (Westport, Conn.; London: Praeger, 1997); Burgwyn, Empire on the Adriatic: Mussolini's Conquest of Yugoslavia, 1941-1943 (New York: Enigma Books, 2005); Luciano Monzali, Il sogno dell'egemonia. L'Italia, la questione jugoslava e l'Europa centrale (1918-1941) (Firenze: Le Lettere, 2010).

51 Patrizia Palumbo, ed., A Place in the Sun: Africa in Italian Africa in Italian Colonial Culture (Berkeley: University of California Press, 2003); Ruth Ben Ghiat and Mia Fuller, eds., Italian Colonialism (New York: Palgrave Macmillan, 2005); Borut Klabjan, "Scramble for Adria»: Discourses of Appropriation of the Adriatic Space Before and After World War I', Austrian History Yearbook, 42 (2011), 16-32; Valeria Deplano, L'Africa in casa: propaganda e cultura coloniale nell'Italia fascista (Firenze: Le Monnier, 2015); Roberta Pergher, Mussolini's Nation-Empire. Sovereignty and Settlement in Italy's Borderlands, 1922-1945 (Cambridge, Mass.: Cambridge University Press, 2017).

52 For a synthetic summary of these problems see Filippo Focardi, 'Il passato conteso. Transizione politica e guerra della memoria in Italia dalla crisi della prima Repubblica ad oggi', in Focardi and Bruno Groppo, eds., L'Europa e le sue memorie. Politiche e culture del ricordo dopo il 1989 (Roma: Viella, 2013), 51-90. 
both public discourse and historiography. ${ }^{53}$ Starting from the mid-1980s various readings claimed to be 'revisionist' with respect to the anti-fascist tradition. Since then, a new public memory has been forged - one that tends to favour the experiences and visions of the victims of twentieth-century violence. Notably, in Italy, national public opinion's previous self-indulgence based on the stereotype of the 'good Italian' has found a new representation in the 'Italians' as being among the 'victims' of the Second World War. ${ }^{54}$

So far marginalised or unspoken events, such as the mass violence in Istria and Trieste between 1943 and 1945 (the so-called foibe), as well as the mass migration of the Italian-speaking communities from the Istrian and Dalmatian coasts after 1945 (the so-called esodo), were recovered into the national communicative circuit. The foibe and the esodo, loaded with their overwhelming symbolic emphasis, have then gradually become the fulcrum of a new policy of memory, sanctioned in 2004 by the approval by law of the Day of Remembrance. Ironically, this new agenda ended up counting Italy among the 'victims' of the Second World War and came into increasing tension and competition with the post-1945 Italian public memory founded on resistance and anti-fascism. ${ }^{55}$

In the context of these new memory policies, historians have played a leading role in rewriting the research agenda of the history of the northern Adriatic region. As Galli della Loggia noted, there was no reference to the events of the 'eastern border' in Pavone's masterpiece of $1991 .{ }^{56}$ Since then, undoubtedly significant efforts have been made to investigate issues and problems hitherto removed or set aside. However, the results of this new historiographical agenda are ambivalent. On the one hand, the knowledge of mass violence, repressive policies and population displacements on the so-called 'eastern border' between 1943 and 1948 has significantly increased, but has been reframed within nationally-focused approaches grounded on long-terms dualistic oppositions between 'Italians' and 'Slavs'. ${ }^{57}$ On the other hand, new analytical tools have opened up the study of the multinational Habsburg and post-Habsburg Adriatic region to comparative European and transnational historical perspectives. They have contributed to a better understanding of the rise of the Upper Adriatic nationalisms in the nineteenth and twentieth centuries, the imperial transformations and transitions from the Habsburg Empire to the Italian nation state and the underlying cultural and social continuities and the projects of conquest of fascism and the repression of national minorities, as well as the construction of long-term memories of violence and conflict. ${ }^{58}$ However, Banti's deconstructive approach to national discourses and representations still waits to be tested and critically reassessed in the light of the complex problems of identification in a multinational border like the northern Adriatic.

The categories of belonging and identification still tend to be examined along national lines. The conceptualisation of new lines of research that draw on a variety of criteria of identification and on a plurality of scales of (local, regional, national and supranational) observation is still absent. On this basis, recent historiography about central Habsburg and post-Habsburg Europe can offer a repertoire of extremely useful and refined instruments, especially referring to the key concept of 'national

\footnotetext{
53 In general see Tony Judt, Postwar: A History of Europe Since 1945 (London: Heinemann, 2005) and most recently, Martin Conway, Western Europe's Democratic Age, 1945-1968 (Princeton: Princeton University Press, 2020).

54 Enzo Collotti, ed., Fascismo e antifascismo: rimozioni, revisioni, negazioni (Roma-Bari: Laterza, 2000).

55 Mila Orlić, 'Se la memoria (non) mi inganna . . . L'Italia e il «confine orientale»: riflessioni sulla storia e sul suo uso pubblico', Acta Histriae, 23, 3 (2015), 475-86; and, more in general, Borut Klabjan, ed., Borderlands of Memory. Adriatic and Central European Perspectives (Oxford, Bern, Berlin: Peter Lang, 2019).

56 Galli Della Loggia, La morte della patria, 59 (footnote 58).

57 Raoul Pupo, Il lungo esodo. Istria: le persecuzioni, le foibe, l'esilio (Milano: Rizzoli, 2005); Marina Cattaruzza, L'Italia e il confine orientale, 1866-2006 (Bologna: Il Mulino, 2007; Eng. ed.: London: Routledge, 2016). Pupo's works derive originally from an interest in Italian foreign policy; Cattaruzza's earlier studies were carried out in the field of social history.

58 See Glenda Sluga, The Problem of Trieste and the Italo-Yugoslav Border: Difference, Identity, and Sovereignty in Twentieth Europe (Albany: Suny Press, 2002); Pamela Ballinger, History in Exile: Memory and Identity at the Borders of the Balkans (Princeton: Princeton University Press, 2003); Guido Crainz, Il dolore e l'esilio. L'Istria e le memorie divise d'Europa (Roma: Donzelli, 2005); Marta Verginella, Il confine degli altri: la memoria giuliana e la questione slovena (Roma: Donzelli, 2008); Dall'Impero austro-ungarico alle foibe. Conflitti nell'area alto-adriatica (Torino: Bollati Boringhieri, 2009).
} 
indifference' as a way of thinking about the multiple loyalties and identifications beyond the national ones, as well as of understanding limits, obstacles and contradictions in state and nation building. ${ }^{59}$ This concept contributes to rethinking the nationalist narratives in the Habsburg/post-Habsburg northern Adriatic. ${ }^{60}$ This can also help renew a long Italian tradition of local and regional history which assessed the long-term structural institutional, social, cultural plurality (the aforementioned 'polycentrism') in the history of the Italian peninsula, before and even after its political unification in the nineteenth century. ${ }^{61}$

\section{Conclusion}

In concluding this short but tortuous journey, I want to argue that a substantial and prominent part of Italian historiography on nationalism, fascism and imperialism continues to follow a research agenda entrenched in the political debates of the 1990s and to structure itself around national problems and categories. In this regard, research is still too much conditioned by the debates and problems concerning the 1943-5 period, which tend to filter the perception and interpretation of the fascist experience as a whole. Additionally, historians still tend to identify and justify their research interests and problems against the backdrop of what was removed, silenced, forgotten or simply and more usually neglected in the post-1945 historiography and public memory. In fact, most of the historical narratives refer in one way or another to a political, cultural and social space defined in a national sense. ${ }^{62}$ In this sense, the historiography inspired by the attempt to question the 'myth of good Italian' is no exception. As explained, some scholars, animated by strong individual initiative, and despite the scarcity of resources that disadvantaged the Italian academic system vis-à-vis others in Western Europe, have accepted the challenge of rewriting their research agenda and have succeeded in moving towards new perspectives that investigate contaminations, hybridisations and circulations of practices and concepts in a transnational sense. However, what seems to be still lacking is a general understanding of interwar Italian history and fascist experience in the synchronic context of European history.

Finally, a more general problem remains open. The fundamental instrument of comparison, when used, is bent to an explicit or implicit comparison between the historical experiences of Italy and those of other 'nations', mostly 'Western' - primarily, France and the United Kingdom, more rarely Germany and Spain. The history of contemporary Italy, be it liberal, fascist or republican, tends to be steeped in the fundamental narrative of an 'anomaly' or 'exception' that clearly emerges with respect to Western European political, social, economic and cultural developments (in various ways understood as normative). A latent or declared sense of 'exceptionalism' and the underlying idea of an Italian Sonderweg to modernity therefore persist. ${ }^{63}$ It is here that a clear shift towards a new comparative perspective would be desirable. The frequent cycles of instability and political and social

59 See Tara Zahra, 'Imagined Noncommunities: National Indifference as a Category of Analysis', Slavic Review (Spring 2010), 93-119; and the many case studies presented in Maarten Van Ginderachter, Jon Fox, eds., National Indifference and Nationalism in Modern Europe (London: Routledge, 2019).

60 Dominique K. Reill, Nationalists Who Fear the Nation: Adriatic Multi-Nationalism in Habsburg Dalmatia, Trieste, and Venice (Stanford: Stanford University Press, 2012); Pamela Ballinger, 'History's Illegibles: National Indeterminacy in Istria', Austrian History Yearbook, 43 (2012), 116-37; Marco Bresciani, 'Lost in Transition? The Habsburg Legacy, State- and Nation-Building, and the New Fascist Order in the Upper Adriatic', in Van Ginderachter, Fox, eds., National Indifference, 56-80; Mila Orlić, 'Né italiani, né slavi. State- and Nation-building jugoslavo nel secondo dopoguerra in Istria', Contemporanea, 4 (Oct.-Dec. 2019), 563-88.

61 The most important example is the Storia d'Italia published by Einaudi since the 1970s and articulated into volume of regional history.

62 For a general survey see Stefan Berger, 'A Return to the National Paradigm? National History Writing in Germany, Italy, France and Britain From 1945 to the Present', Journal of Modern History, 77, 3 (Sept. 2005), 629-78.

63 In this regard, the major effort of rethinking the history of Italy through the perspective of the global history, shaped on the Histoire mondiale de la France (edited by Patrick Boucheron) and conceived by Andrea Giardina, seems to show the same contradictions typical of any national narrative: see Andrea Giardina, ed., Storia mondiale dell'Italia (Roma-Bari: Laterza, 2017). 
conflict; the shortcomings and contradictions of state and nation building; the formation and circulation of nationalist and imperialist, racist and anti-Semitic discourses and practices; the recurrent crises of democratic institutions; the experience of totalitarian fascism; the civil war of 1943-5 and its lacerating and violent inheritance and the liminal role of Italy in the Cold War and the sudden decline of the 'republic of parties' could be better understood through a comparative framework, including both Western and East Central and South-Eastern European history. In this sense, the most important challenge for Italian historians in the near future is to restore the critical importance of contemporary Italian history within a comprehensive European history.

Acknowledgments. I would like to thank the two anonymous reviewers for their helpful comments, and Christian Bailey for his excellent assistance while writing this essay.

Cite this article: Bresciani M (2021). Fascism, Anti-Fascism and the Idea of Nation: Italian Historiography and Public Debate since the 1980s. Contemporary European History 30, 111-123. https://doi.org/10.1017/S0960777320000491 